\title{
DIPLOMATS OR DEFENDANTS? DEFINING THE FUTURE OF HEAD-OF-STATE IMMUNITY
}

\author{
MiCHAEL A. TUNKS
}

\section{INTRODUCTION}

The question of when a country's highest leaders may be haled before a foreign nation's civil or criminal courts to stand trial has long been a murky and unsettled area of law. ${ }^{1}$ In the past year, however, international and American courts have crafted a relatively clear and consistent answer.

In two seminal cases, the International Court of Justice (ICJ) and a U.S. federal district court recognized the immunity of the Congo's Foreign Minister Abdulaye Yerodia Ndombasi ${ }^{2}$ and Zimbabwe's President Robert Mugabe. ${ }^{3}$ These decisions establish a coherent framework for deciding difficult and politically sensitive questions of immunity that addresses the competing goals of promoting international discourse, respecting the sovereign equality of states, and ensuring accountability for serious international crimes. By establishing clear and predictable rules that define when a state's leaders may travel abroad freely without fear of arrest, this framework promises

Copyright $@ 2002$ by Michael A. Tunks.

1. See, e.g., David J. Bederman, International Law Advocacy and Its Discontents, 2 CHI. J. INT'L L. 475, 479 (2001) (discussing the sources of confusion about head-of-state immunity); Joseph W. Dellapenna, Civil Remedies for International Terrorism, 12 DEPAUL Bus. L.J. 169, 190 $(1999 / 2000)$ (suggesting that "if there is such a thing as 'head-of-state immunity,' . . the meaning and scope of that immunity remains completely unclear"); Ved P. Nanda, Human Rights and Sovereign and Individual Immunities (Sovereign Immunity, Act of State, Head-of-State Immunity and Diplomatic Immunity)—Some Reflections, 5 ILSA J. INT'L \& COMP. L. 467, 475-76 (1999) (discussing the unsettled nature of head-of-state immunity under U.S. law); Peter Evan Bass, Note, Ex-Head-of-State Immunity: A Proposed Statutory Tool of Foreign Policy, 97 YALE L.J. 299, 306 (1987) (proposing solutions to "supplant the current confusion" over head-of-state immunity); Shobha Varughese George, Note, Head-of-State Immunity in the United States Courts: Still Confused After All These Years, 64 Fordham L. REV. 1051, 1061 (1995) (explaining the "current confusion plaguing head-of-state immunity").

2. Arrest Warrant of 11 April 2000 (Congo v. Belg.), 41 I.L.M. 536, 549-50, 551-52 (2002) (recognizing the immunity of Yerodia).

3. Tachiona v. Mugabe, 169 F. Supp. 2d 259, 296-97 (S.D.N.Y. 2001). 
to improve nations' ability to conduct crucial diplomatic functions. Moreover, it provides states with certain means of bringing to justice world leaders who violate fundamental principles of international law and basic human decency.

Part I of this Note examines the origins of the head-of-state immunity doctrine, a history that proves crucial in analyzing why some aspects of the doctrine have been discarded while others have been retained. Parts II and III discuss the law of head-of-state immunity under international law and U.S. law, respectively, and describe the developments that have affected the head-of-state immunity doctrine in the past year. Part IV identifies the framework of head-of-state immunity law synthesized in these two recent cases, demonstrates that this framework is a responsible balance between the interests of diplomacy and justice, and suggests ways in which this framework allows the United States to seek accountability for international crimes while preserving strong protection for the leaders of the United States and our allies.

\section{HEAD-OF-STATE IMMUNITY: ORIGINS AND POLICIES}

The principle of head-of-state immunity originally developed from the idea of state sovereign immunity, as the state and its ruler used to be deemed one and the same. ${ }^{4}$ Yet the treatment afforded to heads of state and other top state officials ${ }^{5}$ has also been strongly influenced by the principle of diplomatic immunity, and the three concepts have by now evolved into doctrines wholly distinct from one another. ${ }^{6}$ Nevertheless, to understand the dramatic recent changes in the law of head-of-state immunity, it is essential to examine these closely related doctrines from which the idea of head-of-state immunity descended, and to explore their underlying rationales.

4. Jerrold L. Mallory, Resolving the Confusion Over Head-of-State Immunity: The Defined Rights of Kings, 86 COLUM. L. REV. 169, 170 (1986).

5. The head-of-state immunity doctrine protects not only heads of state, but also heads of government and certain other top state officials, including foreign ministers. See Lafontant v. Aristide, 844 F. Supp. 128, 133 (E.D.N.Y. 1994) (stating that the "determination of who qualifies as a head-of-state is made by the Executive Branch"). The question of precisely which government officials are protected by head-of-state immunity is outside the scope of this Note.

6. See Mallory, supra note 4, at 170-71 ("[D]espite their common origin, head-of-state immunity and sovereign immunity have evolved into separate legal constructs.”). 


\section{A. State Sovereign Immunity}

Rules of sovereign immunity govern the extent to which a state may claim to be free from the jurisdiction of a foreign nation's courts. ${ }^{7}$ Historically, international law recognized a principle of absolute immunity for sovereign states, under which no state could be put on trial without its consent. ${ }^{8}$ This rule reflected the fundamental premise that all states are independent and equal under international law, and the notion that subjecting a state to a foreign court's jurisdiction would be inconsistent with the idea of sovereign equality. ${ }^{9}$ But as countries became more and more involved in commercial activities, international law shifted toward a concept of restrictive sovereign immunity, ${ }^{10}$ under which a state retains immunity from lawsuits based on its official public acts, but may be subject to a foreign state's jurisdiction regarding claims arising out of its private acts, such as commercial behavior. ${ }^{11}$ By consenting to these new standards, states adapted the law of sovereign immunity to fit a changing world in which national governments played more expansive roles outside the sphere of what had traditionally been considered public action. ${ }^{12}$ The shift to restrictive sovereign immunity allowed international law to adjust to more extensive state commercial activity without unduly interfering with the goals of state sovereign equality and independence. ${ }^{13}$

\section{B. Diplomatic Immunity}

Diplomatic immunity, in contrast, gives a form of restrictive immunity to the official agents of a diplomatic staff. ${ }^{14}$ Diplomatic agents

7. Peter Malanczuk, AKehurst's Modern Introduction to InTERnational LAW 118 (7th ed. 1997).

8. Id. at 119.

9. Id. at 118; see also U.N. CHARTER art. 2, para. 1 ("The Organization is based on the principle of the sovereign equality of all its Members.").

10. MALANCZUK, supra note 7, at 119 . Restrictive sovereign immunity is also commonly referred to as qualified sovereign immunity.

11. Mallory, supra note 4, at 173.

12. Most countries, including the United States, have adopted the restrictive view of sovereign immunity, either through legislation or in the courts. MALANCZUK, supra note 7, at 119. However, some countries, most notably South American countries, continue to adhere to the older absolute sovereign immunity rules. Id.

13. See id. at 120 (discussing policies motivating the shift to restrictive sovereign immunity).

14. Vienna Convention on Diplomatic Relations, Apr. 18, 1961, art. 29-38, 23 U.S.T. 3227, 3240-45, 500 U.N.T.S. 95, 110-18. 
are considered inviolable and not subject to arrest ${ }^{15}$ they are absolutely immune from criminal prosecution ${ }^{16}$ and they are immune from civil suits except when the action relates to their private property or their private commercial activities outside the scope of their official functions. ${ }^{17}$ Yet the immunity still belongs to the state, not to the diplomat, and it may be waived if the sending state desires. ${ }^{18}$

The most powerful justification for diplomatic immunity is functional necessity: in the absence of such immunity, diplomats would not be able to effectively represent their countries, and international relations in turn would suffer. ${ }^{19}$ The leading treaty in this field, the Vienna Convention on Diplomatic Relations, endorses the idea of functional necessity by explaining that the treaty's goal is to develop friendly relations between nations and stressing that the purpose of diplomatic immunity is "to ensure the efficient performance of the functions of diplomatic missions." 20

\section{Head-of-State Immunity}

Head-of-state immunity has sought to achieve the goals of both sovereign and diplomatic immunity by (1) recognizing an appropriate degree of respect for foreign leaders as a symbol of their state's sovereign independence; and (2) ensuring that they are not inhibited in performing their diplomatic functions. Heads of state who travel abroad perform crucial and unique diplomatic tasks, and, therefore, a principal purpose of head-of-state immunity is to allow state leaders freely to conduct diplomacy in foreign countries. ${ }^{21}$ Moreover, ensuring

15. Id. art. 29, 23 U.S.T. at 3240, 500 U.N.T.S. at 110.

16. Id. art. 31,23 U.S.T. at 3240,500 U.N.T.S. at 112.

17. Id.

18. Id. art. 32, 23 U.S.T. at 3241, 500 U.N.T.S. at 112.

19. See Joshua D. Groff, A Proposal for Diplomatic Accountability Using the Jurisdiction of the International Criminal Court: The Decline of an Absolute Sovereign Right, 14 TEMP. INT'L \& COMP. L.J. 209, 216 (2000) (discussing functional necessity as "the most popular" justification for diplomatic immunity); Lori J. Shapiro, Foreign Relations Law: Modern Developments in Diplomatic Immunity, 1989 ANN. SURV. AM. L. 281, 283 (1990) (exploring the theoretical bases for diplomatic immunity). Other theories that have been offered to explain the doctrine of diplomatic immunity include: (1) a vision of a diplomat as a personification of the sending state's sovereign; and (2) extraterritoriality—a legal fiction that a diplomat who travels abroad remains in his home country for legal purposes. Id. at 282.

20. Vienna Convention on Diplomatic Relations, supra note 14, preamble, 23 U.S.T. at 3230, 500 U.N.T.S. at 96.

21. See Mallory, supra note 4, at 179 ("Each state, with the expectation of being accorded similar treatment, grants foreign heads of state at least the degree of immunity necessary for them to perform their duties within that state without being subject to detention or arrest."). 
that heads of state may travel freely abroad serves the traditional aims of sovereign immunity, because subjecting a state's leader to the jurisdiction of a foreign court infringes to some degree on that state's sovereignty.

Historically, heads of state-like states themselves-were absolutely immune for acts committed either in a public or a private capacity, and therefore many countries felt no practical need to distinguish between head-of-state immunity and state sovereign immunity. ${ }^{22}$ But as the international community moved toward a restrictive form of sovereign immunity, stripping away a state's immunity for private or commercial acts, it became unclear whether the doctrine of headof-state immunity would follow that course as well, or whether international law would preserve a greater degree of personal inviolability for world leaders. ${ }^{23}$ The shift to restrictive sovereign immunity demonstrated that the policies justifying that doctrine could in some instances be outweighed by other important state interests. Granting immunity to heads of state was justified in part by these very same policies, but also by functional diplomatic considerations. Consequently, nations began thinking about head-of-state immunity as a distinct legal concept, and recognized the need to reconsider the extent to which the goals of sovereign equality and functional necessity together could justify exempting heads of state from judicial process abroad. $^{24}$

A strong head-of-state immunity doctrine would prevent states from bringing some violators of the most serious international crimes to justice, a consequence that seemed at odds with the international community's ever-increasing focus on protecting fundamental human

22. See MALANCZUK, supra note 7, at 118-19 (discussing head-of-state immunity as part of the doctrine of sovereign immunity).

23. See Mallory, supra note 4, at 179 (discussing the "absence of a legal standard for determining when heads of state are entitled to immunity" ).

24. See, e.g., Lafontant v. Aristide, 844 F. Supp. 128, 135-37 (E.D.N.Y. 1994) (explaining that the codification of the restrictive theory of sovereign immunity in the United States in the Foreign Sovereign Immunities Act did not codify the law of head-of-state immunity, and asserting that "the view that the FSIA is inapplicable to a head-of-state comports with both the history of the FSIA and the underlying policy of comity"); Amber Fitzgerald, The Pinochet Case: Head-of-State Immunity Within the United States, 22 WHITTIER L. REV. 987, 1006 (2001) ("The end result has been that the enactment of the FSIA divided the principles of sovereign immunity and head-of-state immunity."). 
rights. ${ }^{25}$ As the international legal system at the close of the twentieth century concentrated increasingly on safeguarding human rights, states consented to accept some limitations on their sovereignty to ensure more accountability for violations of these basic norms. ${ }^{26}$ In addition, bestowing immunity upon heads of state can give human rights violators an incentive to keep power at all costs to retain the cloak of immunity that runs with the office, particularly if former heads of state are not entitled to the same benefits. Motivated by the desire for accountability, many state policymakers weighing the benefits of immunity against the interests of justice, decided it would be best to whittle away at the shield of immunity historically enjoyed by heads of state. ${ }^{27}$

On the other hand, immunity from foreign jurisdiction has been recognized throughout human history as an essential tool in conducting foreign affairs. ${ }^{28}$ Head-of-state immunity allows a nation's leader to engage in his official duties, including travel to foreign countries, without fearing arrest, detention, or other treatment inconsistent with his role as the head of a sovereign state. ${ }^{29}$ Without the guarantee that they will not be subjected to trial in foreign courts, heads of state may simply choose to stay at home rather than assume the risks of engaging in international diplomacy abroad. For example, when Belgium began publicly entertaining the idea of bringing Ariel Sharon to trial, the Israeli Prime Minister was essentially unable to visit the European Union Headquarters in Brussels, ${ }^{30}$ and Israeli legal

25. See Hari M. Osofsky, Note, Domesticating International Criminal Law: Bringing Human Rights Violators to Justice, 107 YALE L.J. 191, 206 (1997) ("In order for human rights protections to have any real meaning, they must be enforced; if violators escape punishment, the prohibitions are merely declaratory.").

26. See id. at 205 (explaining that the erosion of state sovereignty was the price paid for the creation of a legal regime based on respect for international human rights).

27. See Joseph W. Dellapena, International Decisions, Lafontant v. Aristide, 844 F. Supp. 128 (E.D.N.Y. 1994), 88 AM. J. INT'L L. 528, 531-32 (1994) (arguing that the interests of justice are paramount in cases where a state or a state official is engaged in private or commercial acts).

28. See Groff, supra note 19, at 213 (tracing the history of diplomatic immunity to ancient Greek city-states and to Biblical times); Numbers 21:21-22 (Revised Standard) ("Then Israel sent messengers to Sihon king of the Amorites, saying: 'Let me pass through your land; we will not turn aside into field or vineyard; we will not drink the water of a well; we will go by the King's Highway, until we have passed through your territory."').

29. See Fitzgerald, supra note 24, at 1002 (discussing the role of head-of-state immunity in promoting international respect in foreign relations).

30. Sharon 'War Crimes' Hearing Delayed, BBC News, at http://news.bbc.co.uk/1/hi/world/ middle_east/1577630.stm (Oct. 3, 2001) (on file with the Duke Law Journal). 
advisors began compiling a list of nations that purported to exercise universal jurisdiction over criminal offenses in such a manner. ${ }^{31}$

Moreover, supporters of head-of-state immunity feared that the decay of the immunity doctrine would lead to the increased use of civil and criminal lawsuits as a weapon against unpopular political figures. Israeli Attorney General Elyakim Rubenstein, without providing details, claims to have many clear indications that lawsuits against Sharon and other top Israeli officials are "conducted in the context of a premeditated campaign involving people with clear political interests." ${ }^{32}$ Likewise, former U.S. Secretary of State Henry Kissinger has been very critical of attacks on the traditional head-ofstate immunity doctrine, and reports indicate that Kissinger himself is reluctant to travel in several countries. ${ }^{33}$ Kissinger argues that the international legal system should not develop into "a way of conducting political battles [where] the various contestants will pursue each other in courts around the world." ${ }^{34}$

\section{HEAD-OF-STATE IMMUNITY UNDER INTERNATIONAL LAW}

At the close of the twentieth century, international law increasingly began to identify situations in which heads of state would not be entitled to immunity in foreign courts. Correspondingly, it became quite unclear to states and scholars what still remained of the traditional head-of-state immunity doctrine in modern times. In 2002, the ICJ stepped in to resolve the debate, providing a relatively clear and authoritative framework for deciding head-of-state immunity cases under international law.

31. Herb Keinon, Israel Compiling List of States With 'Universal Jurisdiction', JERUSALEM PosT, July 27, 2001, at 4A. Moreover, because immunity is based on international comity, any state that stops recognizing a foreign leader's immunity cannot expect its own leader to be shielded from lawsuits while traveling abroad, even when in countries that generally respect the immunity of foreign heads of state. See Mallory, supra note 4, at 169 ("[A] state's ability to grant or deny immunity is generally restrained only by considerations of reciprocity, that is, how other states will, in turn, treat its alien in their territory.").

32. Keinon, supra note 31, at 4A (quoting Elyakim Rubenstein, Attorney General, Israel).

33. See All Things Considered: New Trend Toward Universal Jurisdiction (National Public Radio broadcast, Aug. 8, 2001), 2001 WL 9435868 (noting that authorities in Chile, Argentina, and France all want Kissinger to testify about human rights violations that took place in Chile under the Pinochet regime when the U.S. was supporting that dictatorship).

34. Id. 


\section{A. The State of International Law before the Yerodia Case}

During the past few years, the international law of head-of-state immunity has evolved at an astoundingly rapid pace. ${ }^{35}$ No treaty has been signed to clarify or alter head-of-state immunity law; instead, the law has changed through the development of international custom. ${ }^{36}$ International customary law consists of two basic elements: objective state practice, and states' subjective belief that their behavior is obligatory under international law, an element known as opinio juris. ${ }^{37}$ Therefore, to monitor the development of the customary law of head-of-state immunity, one should analyze how national and international courts have addressed recent immunity questions, how states have reacted to these decisions, what actions political branches have taken with respect to immunity issues, and any general statements nations have made about the degree of immunity enjoyed by heads of state. $^{38}$

Recent state practice has drawn a sharp distinction between former heads of state and current heads of state, as courts across the world have been much more willing to subject former leaders to their jurisdiction. ${ }^{39}$ After British authorities arrested former Chilean dicta-

35. See Curtis A. Bradley \& Jack L. Goldsmith, Pinochet and International Human Rights Litigation, 97 MICH L. REV. 2129, 2130 (1999) (discussing the "growing tension between the international law principle of sovereign equality and the quest for universal justice" that surrounds the question of head-of-state immunity); Mallory, supra note 4, at 179 (noting the current confusion that surrounds the issue, and stating that "since there is no agreement on the degree of immunity that attaches to the status of head of state, there is no applicable standard that can be viewed as customary international law").

36. International custom is recognized as one of the four sources of international law. Statute of the International Court of Justice, Oct. 24, 1945, art. 38, para. 1, 59 Stat. 1031, 1060. The other recognized sources are treaties, general principles of law, and the writings of judges and scholars as a subsidiary source. Id.

37. Military and Paramilitary Activities (Nicar. v. U.S.), 1986 I.C.J. 14, 97 (June 27); see also Asylum Case (Colom. v. Peru), 1950 I.C.J. 266, 276-77 (Nov. 20) (noting that a rule of customary international law must derive from constant and uniform usage); MICHAEL BYERS, CUSTOM, POWER AND THE POWER OF RULES: INTERNATIONAL RELATIONS AND CUSTOMARY INTERNATIONAL LAW 19 (1999) (explaining that the opinio juris element establishes that "only that behaviour which is considered legally relevant is regarded as capable of contributing to the process of customary international law").

38. See MALANCZUK, supra note 7, at 39:

The main evidence of customary law is to be found in the actual practice of states, and a rough idea of a state's practice can be gathered from ... reports of actions taken by states, and from statements made by government spokesmen ... and also from a state's laws and judicial decisions.

39. See, e.g., Regina v. Bow St. Metro. Stipendary Magistrate, [2000] 1 A.C. 147, 205-06 (H.L. 1999) (denying immunity to Pinochet and allowing the extradition process to proceed on charges of torture in pursuance to a conspiracy to commit torture). 
tor Augusto Pinochet, on an international arrest warrant issued by Spain, Pinochet, who had traveled to London for back surgery, attempted to resist extradition based on his status as a former head of state. ${ }^{40}$ The British Law Lords denied him immunity for acts of torture committed after 1988, when the Torture Convention came into effect in the United Kingdom. ${ }^{41}$ Even though the ruling was decided on narrow grounds, ${ }^{42}$ for most scholars it sounded the death knell for headof-state immunity for international crimes with respect to former heads of state, even when the crimes were perpetrated while the leader was in office. ${ }^{43}$ While former heads of state still retain immunity for the official acts they committed while in power, they enjoy no protection for their international crimes, because such serious abuses cannot fall within the scope of a head of state's legitimate functions. ${ }^{44}$ Even though Pinochet served as a head of state at the time, international law deems acts of torture so far outside the bounds of legitimate state action that he must be considered a private actor with respect to such conduct. ${ }^{45}$

The abrogation of immunity for the private acts of former heads of state, including international crimes in any context, is in harmony with the twin purposes of the head-of-state immunity doctrine: respecting state sovereign equality and promoting diplomatic functions. Because crimes against humanity, torture, and other international crimes are outside the scope of what can be considered a state's official public functions, seeking accountability for these acts does not in-

40. Bradley \& Goldsmith, supra note 35, at 2133.

41. See Michael Byers, The Law and Politics of the Pinochet Case, 10 DUKE J. COMP. \& INT'L L. 415, 434 (2000) (explaining that the final Law Lords ruling was based on the Torture Convention, not on international custom); Fitzgerald, supra note 24, at 1001 (discussing the ratification of the Torture Convention). Yet even if the abrogation of former head-of-state immunity had not already become customary law by the date of the Pinochet decision, the decision itself certainly contributed mightily toward the development of this international customary rule. Eventually, U.K. Home Secretary Jack Straw decided not to extradite Pinochet on other grounds-Pinochet had fallen severely ill and was not fit to stand trial. Byers, supra, at 438.

42. See Byers, supra note 41, at 434 (describing the "conservative" nature of the ruling).

43. See Charles Pierson, Pinochet and the End of Immunity: England's House of Lords Holds that a Former Head of State Is Not Immune for Torture, 14 TEMP. INT'L \& COMP. L.J. 263, 326 (2000) (declaring that no immunity exists for former heads of state for crimes against humanity).

44. See id. at 323 (reporting that a majority of the Law Lords in the Pinochet case found that acts performed by state officials under the color of state law are not necessarily state acts when the conduct violates international law).

45. See id. at 299 ("International law, as reflected in state practice, has rejected torture and taking of hostages as official functions of governments."). 
fringe on a state's sovereignty, or at least not so much as to outweigh the benefits of stronger human rights enforcement. This is exactly the rationale that led to the adoption of restrictive sovereign immunity for states, ${ }^{46}$ and nothing suggests that the goal of protecting state sovereign equality should favor a nation's head of state over the state itself. Furthermore, holding former heads of state accountable for their international crimes does not interfere with the goal of promoting diplomatic functions, because exercising jurisdiction over a former leader would not prevent current diplomats from traveling abroad and would not otherwise unduly disrupt international relations. ${ }^{47}$

Much more controversy has surrounded the law of head-of-state immunity for current leaders, and at least some state practice has emerged that suggests abrogating immunity even for sitting world leaders, at least for the most serious international offenses. ${ }^{48} \mathrm{~A}$ Belgian lawsuit alleging that Israeli head of state Ariel Sharon took part in a 1982 massacre of Palestinian refugees in Lebanon and a suit in response against Palestinian leader Yasser Arafat for a series of murders and bombings in Israel serve as prominent examples. ${ }^{49}$ Sensing the possibility of using the Belgian courts as a forum to try state leaders, a group of Cuban exiles followed suit, bringing a civil action against Fidel Castro in Belgium based on allegations of torture, persecution, and false imprisonment. ${ }^{50}$

The Rome Statute of the International Criminal Court (Rome Statute), a multilateral treaty, lent even more force to the argument that sitting head-of-state immunity was eroding under customary international law. The Rome Statute explicitly denies immunity to heads of state, declaring that "official capacity as a Head of State or

46. See supra notes 7-12 and accompanying text.

47. E.g., In re Estate of Ferdinand Marcos, 25 F.3d 1467, 1472 (9th Cir. 1994) (noting that a lawsuit against former Philippine head of state Marcos regarding private acts he engaged in while serving as head of state "does not implicate any of the foreign diplomatic concerns involved in bringing suit against another government in United States courts").

48. See Cuban Exiles Act Against Castro, CNN.com, at http://europe.cnn.com/2001/ WORLD/europe/10/04/belgium.castro/ (Oct. 4, 2001) (on file with the Duke Law Journal) (naming Cuban President Fidel Castro, Israeli Prime Minister Ariel Sharon, and Iraqi dictator Saddam Hussein as heads of state who at the time faced possible trials in Belgium for international crimes).

49. Chris Morris, Arafat Lawsuit Filed in Belgian Court, BBC News, at http://news.bbc.co.uk/1/hi/world/europe/1679044.stm (Nov. 27, 2001) (on file with the Duke Law Journal). A representative of the group filing suit has said that the group's members decided to file suit in Belgium after they saw how the court reacted to the complaint against Sharon. Id.

50. Cuban Exiles Act Against Castro, CNN.com, at http://europe.cnn.com/2001/WORLD/ europe/10/04/belgium.castro/ (Oct. 4, 2001) (on file with the Duke Law Journal). 
Government ... shall in no case exempt a person from criminal responsibility under this Statute." ${ }^{51}$ United Nations (UN) Secretary General Kofi Annan echoed that the goal of the International Criminal Court (ICC) is to "ensure that no ruler, no State, no junta, and no army anywhere can abuse human rights with impunity." Statute provides for jurisdiction when the defendant's state is a party to the treaty, or when the crime took place on the territory of a state party. ${ }^{53}$ When the defendant head of state is a national of a state party to the treaty, head-of-state immunity is not really abrogated; rather, the state that holds the immunity has merely waived it in advance or delegated its power to try its own leaders. ${ }^{54}$ However, when the proposed court's jurisdiction is based simply on a delegation from states with territorial jurisdiction, ${ }^{55}$ the ICC, according to the plain text of the Rome Statute, purports to claim jurisdiction over heads of state of nations that have not consented to the court's jurisdiction. ${ }^{56}$

The Statutes of the International Criminal Tribunals for the Former Yugoslavia and Rwanda (ICTY and ICTR) also provide that

51. Rome Statute of the International Criminal Court, July 17, 1998, art. 27, U.N. Doc. A/CONF.183/9 (1998), 37 I.L.M. 999, 1010.

52. Rome Statute of the International Criminal Court: Overview, UN.org, at http://www.un. org/law/icc/general/overview.html (last visited Oct. 19, 2002) (emphasis added).

53. Rome Statute of the International Criminal Court, supra note 51, art. 12, 37 I.L.M. at 1017. The treaty also recognizes that the UN Security Council would have the power to refer a dispute to the ICC even if the conditions in Article 12 are not met. Id. art. 13, 37 I.L.M at 1012; see also infra notes 57-59 and accompanying text.

54. Cf. Pierson, supra note 43, at 273 ("Head-of-state immunity exists to protect states, not individual leaders.").

55. See Madeline Morris, The Democratic Dilemma of the International Criminal Court, 5 BufF. CRIM. L. REV. 591, 594 (2002) ("[T]he ICC's jurisdiction arises from the delegation of jurisdiction by the states parties."); See generally Madeline Morris, High Crimes and Misconceptions: The ICC and Non-Party States, 64 LAW \& CONTEMP. Probs. 13 (Winter 2001) (examining whether states have any power to delegate criminal jurisdiction to international tribunals).

56. Although this claim is further limited only to instances in which the country of the head of state is unable or unwilling to genuinely prosecute or investigate the allegations, it still marks significant state practice purporting to abrogate the immunity of sitting heads of state. See generally Rome Statute of the International Criminal Court, supra note 51, art. 17, 37 I.L.M. at 1012 . 
sitting heads of state are not immune before those tribunals. ${ }^{57}$ Yet these statutes lend little support to the development of a general international customary rule, since they were authorized by the UN Security Council under its Chapter VII powers to deal with specific threats to international peace and security. ${ }^{58}$ The ICTY and ICTR Statutes do not recognize a general change in the international law of head-of-state immunity; on the contrary, the Security Council has authorized a limited abrogation of the customary rule for a specific purpose, namely to restore international peace and security in two unstable regions. Because states consented to give the Security Council this power in the UN Charter, the ICTY and ICTR Statutes do not change the principle that no head of state may be put on trial without the consent of his home country. ${ }^{59}$

Recent state practice also presents a number of examples that suggest that the doctrine of immunity for current heads of state is still alive and well, even with respect to the most serious international crimes. In March, 2001, France's highest court, the Cour de Cassation, held that Libyan head of state Muammar el-Qaddafi was entitled to immunity in a suit alleging that Qaddafi was responsible for bombing

57. Statute of the International Criminal Tribunal for the Former Yugoslavia, art. 7, S.C. Res. 827, U.N. SCOR, 48th Sess., 3217th mtg., Annex, U.N. Doc. S/Res/827/Annex (1993), reprinted in 32 I.L.M. 1192, 1194 ("The official position of any accused person, whether as Head of State or Government or as a responsible Government official, shall not relieve such person of criminal responsibility ...."); Statute of the International Criminal Tribunal for Rwanda, art. 6, S.C. Res. 955, U.N. SCOR 49th Sess., 3453d mtg. at 16, U.N. Doc. S/Res/955 (1994) [hereinafter ICTR Statute] (same). Indeed, the ICTY has exercised its jurisdiction over former Yugoslav President Slobodan Milosevic on war crimes and genocide charges arising out of the conflicts in Croatia, Bosnia, and Kosovo. See generally Joseph Lelyveld, The Defendant: Slobodan Milosevic's Trial, and the Debate Surrounding International Courts, NEW YORKER, May 27, 2002.

58. See S.C. Res. 827 , U.N. SCOR, 48th Sess., 3217th mtg. at 29, U.N. Doc. S/Res/827 (1993) (establishing the ICTY under its Chapter VII powers, and determining that ethnic cleansing in the former Yugoslavia constituted a threat to international peace and security); S.C. Res. 955, U.N. SCOR, 49th Sess., 3453rd mtg. at 15, U.N. Doc. S/Res/955 (1994) (establishing the ICTR under its Chapter VII powers, and determining that genocide and other large-scale human rights abuses in Rwanda caused a threat to international peace and security).

59. Article 39 grants the Security Council the power to determine the existence of a threat to the peace, a breach of the peace, or an act of aggression. U.N. CHARTER art. 39. After making that subjective determination, the Security Council has the extremely broad power under Article 41 to implement any measures it deems appropriate, not involving the use of force, to restore international peace and security. Id. art. 41. All UN member states are then bound to accept and carry out the Security Council decision. Id. art. 25. 
a French DC-10 aircraft in an attack that killed 170 people. ${ }^{60}$ The decision reversed a lower court ruling that had refused to recognize the sitting Libyan leader's head-of-state immunity. ${ }^{61}$ In Spain, the National Court decided in 1999 that it had no authority to prosecute sitting Cuban head of state Fidel Castro. ${ }^{62}$ Similarly, the United States has denied immunity to former heads of state,$^{63}$ but has never abrogated the immunity of a sitting head of state or head of government. ${ }^{64}$ Furthermore, even though some international agreements have called for stripping away head-of-state immunity, and although some countries have considered taking jurisdiction over foreign leaders, it is significant that no nation has yet gone so far as to actually pass judgment against a sitting head of state. ${ }^{65}$

\section{B. The ICJ's Yerodia Arrest Warrant Decision}

On April 11, 2000, a Belgian investigating judge issued an international arrest warrant in absentia against Abdulaye Yerodia Ndombasi, the Democratic Republic of the Congo's Minister of Foreign Affairs. ${ }^{66}$ The warrant accused Yerodia of crimes against humanity and grave breaches of the 1949 Geneva Conventions and their Additional Protocols for delivering speeches inciting racial hatred. ${ }^{67}$ Belgium asserted that it was exercising its universal jurisdiction to try international crimes, and Belgian law did not recognize any special immuni-

60. Gadhafi Will Not Face Bomb Charge, CNN.com, at http://europe.cnn.com/2001/ WORLD/europe/france/03/13/crime.france.gaddafi/ (Mar. 14, 2001) (on file with the Duke Law Journal).

61. Id.

62. Fitzgerald, supra note 24, at 1012-13.

63. In re Estate of Ferdinand Marcos, 25 F.3d 1467, 1471 (9th Cir. 1994).

64. See Tachiona v. Mugabe, 169 F. Supp. 2d 259, 288, 296-97 (S.D.N.Y. 2001) (recognizing the immunity of Zimbabwe's sitting president, Robert Mugabe); Saltany v. Reagan, 702 F. Supp. 319, 320 (D.D.C. 1988) (finding sitting British Prime Minister Margaret Thatcher immune from suit in the United States).

65. Cf. MALANCZUK, supra note 7, at 43 ("[S]tate practice also includes omissions; many rules of international law forbid states to do certain acts, and, when proving such a rule, it is necessary to look not only at what states do, but also at what they do not do.")

66. Arrest Warrant of 11 April 2000 (Congo v. Belg.), 41 I.L.M. 536, 541 (2002).

67. Id. 
ties arising from any person's capacity as a foreign official. ${ }^{68}$ The Democratic Republic of the Congo in turn protested the arrest warrant's validity under international law, and consequently brought proceedings against Belgium in the ICJ in the Hague. ${ }^{69}$ In addition to the case against Yerodia, Belgium was also considering whether to put Israeli Prime Minister Ariel Sharon, Cuban President Fidel Castro, and Iraqi leader Saddam Hussein on trial for crimes against humanity. ${ }^{70}$

Considering the justifications for the head-of-state immunity doctrine and recent state practice, ${ }^{71}$ the ICJ in the Yerodia case declared that it "has been unable to deduce from this practice that there exists under customary international law any form of exception to the rule according immunity from criminal jurisdiction and inviolability to incumbent Ministers for Foreign Affairs." 72 The ICJ emphasized that the nature of a head of state or foreign minister's office requires him to travel to other nations without apprehension that he could be ex-

68. Id. at 541-42. It is generally accepted that any state may try international crimes such as genocide, war crimes, crimes against humanity, torture, or international terrorism-regardless of (1) where the crime occurred; (2) the nationality of the defendant or the victim; and (3) whether that state's security interests are at stake-under the principle of universal jurisdiction. See Osofsky, supra note 25, at 192 ("[U]niversal jurisdiction stems from the notion that some international prohibitions are so important that a violation of them by anyone, anywhere, warrants any nation's taking jurisdiction."). However, there is no clear consensus regarding the scope of the crimes that are subject to universal jurisdiction, or even regarding the definition of some of these crimes. See id. at 198 ("[I]nternational consensus of universal jurisdiction exists only with regard to a few norms ....").

69. Arrest Warrant of 11 April 2000, 41 I.L.M. at 538.

70. Cuban Exiles Act Against Castro, CNN.com, at http://europe.cnn.com/2001/WORLD/ europe/10/04/belgium.castro/ (Oct. 4, 2001) (on file with the Duke Law Journal).

71. Arrest Warrant of 11 April 2000, 41 I.L.M. at 551 ("The Court has carefully examined State practice, including national legislation and those few decisions of national higher courts .... The Court has also examined the rules concerning the immunity or criminal responsibility of persons having an official capacity contained in the legal instruments creating international criminal tribunals ....").

72. Id. All exceptions to a nation's complete territorial power must be traced back to state consent, and for centuries all states have agreed not to subject foreign leaders to judicial process within their territory. See Schooner Exch. v. McFaddon, 11 U.S. (7 Cranch) 116, 136-37 (1812) ("The world being composed of distinct sovereignties, possessing equal rights and equal independence, whose mutual benefit is promoted by intercourse with each other . . . sovereigns have consented to a relaxation in practice, in cases under certain peculiar circumstances, of that absolute and complete jurisdiction within their respective territories ...."). Therefore, to change the well-established custom of sitting head-of-state immunity states would have to consent to the change, either by ratifying a treaty or by developing international customary law through consistent state practice and a belief that this state practice reflects a new legal norm. See supra notes 36-38 and accompanying text. Despite the existence of some state practice to the contrary, for the most part, states have continued to assert that immunity for sitting heads of state, with very limited exceptions, is essential to the proper functioning of international relations. 
posed to legal liability or criminal punishment. ${ }^{73}$ Consequently, a sitting head of state's immunity, unlike that of a former head of state, cannot depend on whether the crime alleged involved his actions in a private capacity or an official capacity. ${ }^{74}$

Rather, the ICJ observed that the only exceptions to a head of state's immunity under international law are: (1) that a head of state is not immune under international law from process in his own country; (2) likewise, a head of state's home country may waive his immunity in foreign courts; (3) a former head of state is not immune for acts committed before or after his period in office or for private acts (including international crimes) committed while in office; and (4) a head of state enjoys no immunity when that immunity has been validly abrogated by an international tribunal. ${ }^{75}$

State practice since the ICJ's decision demonstrates that states have accepted the principles explained by the ICJ, substantially resolving years of confusion over the scope of head-of-state immunity under international law. Most prominently, in response to the ICJ's opinion, the Belgian government retreated from any assertion that putting a sitting foreign head of state on trial is justified under international law, and the Belgian judiciary has declared the case against Ariel Sharon inadmissible. "The judgment is clear," said Jan Devadder, a legal advisor in the Belgian Foreign Ministry. "The court has

73. Arrest Warrant of 11 April 2000, 41 I.L.M. at 549-50 ("In the performance of these functions, [a head of state or foreign minister] is frequently required to travel internationally, and thus must be in a position freely to do so whenever the need should arise.").

74. Id. at 550 .

75. Id. at 551-52. The ICJ lists the International Criminal Court as an example of a tribunal that may validly abrogate a head-of-state's immunity where it has jurisdiction. Id. at 552. However, it is important to recognize that such an assertion most likely holds true only with respect to heads of state whose home country has assented to ICC jurisdiction. See supra notes 51-56 and accompanying text. The ICC derives its jurisdiction from authority delegated by member states. Leaving aside the frequently debated question of whether states possess any power to delegate their jurisdiction to other entities, it is clear that they may not delegate authority that they do not possess in the first instance. See supra note 55. A head of state is not immune under international law in the courts of his own nation, and a nation may waive the immunity of its own head of state; therefore that state may be able to delegate its jurisdiction over its own head of state to the ICC, or, alternatively, waive the head of state's immunity in advance. However, no other country has jurisdiction over a third party's head of state, and, consequently, no two states (or group of states) may agree by treaty to waive the immunity of a third party's head of state without that other nation's consent. Therefore, the Rome Statute's purported jurisdiction over the heads of state of nonparties is best viewed as an ultimately unsuccessful attempt to modify customary international law.

76. Belgium Bars Sharon War Crimes Trial, BBC News, at http://news.bbc.co.uk/2/hi/world/ Europe/2066808.stm (Jun. 26, 2002) (on file with the Duke Law Journal). 
clearly ruled government leaders and heads of state enjoy total immunity from prosecution. The Sharon case, in my opinion, is closed."77

\section{HEAD-OF-STATE IMMUNITY UNDER U.S. LAW}

Although some federal courts in the 1980s and 1990s had addressed questions of head-of-state immunity under U.S. law, all of this case law predated the dramatic shift in the international law of head-of-state immunity sparked by the high-profile Pinochet case. Therefore, when the Mugabe case reached a federal district court in New York, that court faced unresolved questions of whether the American domestic law of head-of-state immunity is consistent with the framework that was developing under international law, and if so, how the two systems interact together.

\section{A. The State of U.S. Law before the Mugabe Case}

In the United States, the distinction between the law of head-ofstate immunity and the law of state sovereign immunity began to be gradually recognized in the second half of the twentieth century. ${ }^{78}$ After the Second World War, the United States decided to adopt the restrictive form of sovereign immunity, and the State Department notified the international community of this policy shift in the 1952 Tate letter. ${ }^{79}$ However, Congress did not codify any comprehensive rules outlining restrictive sovereign immunity until it approved the Foreign Sovereign Immunities Act (FSIA) in $1976 .{ }^{80}$ The FSIA allows American courts to take jurisdiction over foreign states in certain enumerated actions, such as those involving commercial activities carried on in the United States. ${ }^{81}$ The act defines a foreign state as including both the state itself and its political subdivisions, agencies, and instrumentalities, but it is noticeably silent with respect to foreign heads of state. ${ }^{82}$

77. Andrew Osborn, Sharon Cannot Be Tried in Belgium, Says Court, GUARDIAN (London), Feb. 15, 2002, at 20.

78. See Lafontant v. Aristide, 844 F. Supp. 128, 136-37 (E.D.N.Y. 1994) (discussing the legislative history of the Foreign Sovereign Immunities Act).

79. Tachiona v. Mugabe, 169 F. Supp. 2d 259, 270-71 (S.D.N.Y. 2001).

80. Id. at 272-73.

81. Foreign Sovereign Immunities Act, 28 U.S.C. § 1602-1611 (2000).

82. Id. $\$ 1603(\mathrm{a})$. An "agency or instrumentality of a foreign state" is further defined as any entity that: (1) is a separate legal person, corporate or otherwise; (2) is an organ of the state or political subdivision, or is owned primarily by the state or political subdivision; and (3) is not a 
Since the FSIA was enacted, U.S. courts have consistently read it to encompass only state sovereign immunity, and not foreign head-ofstate immunity. ${ }^{83}$ This interpretation is consistent with the legislative history of the act, and it also recognizes the differing policy goals that the two distinct forms of immunity address. Legislative history demonstrates that the primary purpose of the FSIA was to provide for jurisdiction over foreign state-owned companies, which had become increasingly influential in Communist countries; the act was never intended to affect diplomats or heads of state. ${ }^{84} \mathrm{~A}$ Justice Department official, Bruno Ristau, made this point clear during the congressional hearings by affirming that the FSIA would allow U.S. courts to take jurisdiction over the German state airline Lufthansa, but reminding lawmakers that "we are not talking... in terms of permitting suit against the Chancellor of the Federal Republic .... That is an altogether different question." ${ }^{, 85}$ The enactment of the FSIA signifies that the United States recognizes sovereign immunity and head-of-state immunity as distinct, though related, legal ideas. ${ }^{86}$

In the United States, although the law of diplomatic immunity is governed by an international treaty and the law of state sovereign immunity is governed by an act of Congress, the responsibility for designing legal standards for resolving head-of-state immunity questions has been left to the courts. ${ }^{87}$ However, U.S. courts have been reluctant to play too great of a role in deciding when to hold foreign leaders accountable for their acts, recognizing that the decision to deny the immunity of a foreign head of state can cause serious international po-

citizen of an American state and has not been created under the laws of any third country. Id. $\S$ 1603(b).

83. See Lafontant, 844 F. Supp. at 136 ("No case has, however, construed 'agency or instrumentality' [in $\S 1603$ of the FSIA] to include a head-of-state.").

84. See id. at 137 (discussing the purposes of the FSIA); H.R. REP. No. 94-1487, at 12 (1976), reprinted in 1976 U.S.C.C.A.N. 6604, 6610 (explaining that the FSIA was not "intended to affect either diplomatic or consular immunity").

85. Fitzgerald, supra note 24, at 1005 n.131 (quoting Immunities of Foreign States: Hearing on H.R. 3493 Before the Subcomm. on Claims and Governmental Relations of the House Comm. on the Judiciary, 93d Cong., 1st Sess. 16 (1976) (statement of Bruno Ristau, Chief, Foreign Litigation Unit, Civil Division, Dept. of Justice)).

86. See Mallory, supra note 4, at 170-71 (contrasting head-of-state immunity, sovereign immunity, and diplomatic immunity under U.S. law).

87. See supra notes 14-20 and accompanying text (discussing the Vienna Convention on Diplomatic Relations); supra notes 78-82 and accompanying text (discussing the Foreign Sovereign Immunities Act). 
litical ramifications. ${ }^{88}$ As the Second Circuit explained, "the judicial branch is not the most appropriate one to define the scope of immunity for heads-of-state ... . [B]ecause the field of foreign relations is largely confided to the President by Article II of the Constitution, the executive branch naturally has greater experience and expertise in this area." $"$ When the executive branch decides that a foreign leader ought to receive immunity, federal courts accept this determination as binding, deeming it a nonjusticiable political question. ${ }^{90}$ Consequently, the courts may explore the issue of how much immunity is enjoyed by foreign heads of state only when the executive branch is silent. ${ }^{91}$ Still, as the Supreme Court has long emphasized, "In the absence of recognition of the claimed immunity by the political branch of the government, the courts may decide for themselves whether all the requisites of immunity exist."

In practice, the State Department has preempted the judiciary from making immunity determinations for heads of state by filing formal "suggestions of immunity" with the court, through the Justice Department. ${ }^{93}$ The Supreme Court recognizes that these suggestions are binding, stressing that the executive branch must be able to settle certain claims through diplomatic channels, rather than through litigation in the American courts. ${ }^{94}$ The State Department used to follow

88. See Doe v. United States, 860 F.2d 40, 45 (2d Cir. 1988) (noting that the executive branch is better equipped than the judiciary to tackle problems that require flexible responses in the interest of international comity).

89. Id.

90. Republic of Mexico v. Hoffman, 324 U.S. 30, 35 (1945) (“[T]he courts should not so act as to embarrass the executive arm in its conduct of foreign affairs .... It is therefore not for the courts to deny an immunity which our government has seen fit to allow ...."); see also Baker v. Carr, 369 U.S. 186, 210 (1962) (explaining that the doctrine of nonjusticiability of political questions derives from the idea of separation of powers between the branches of government).

91. Hoffman, 324 U.S. at 34-35. Nevertheless, many courts have addressed this issue extensively in dicta, even when deciding the case on the ground that the executive branch's determination of the issue is not reviewable by the courts. E.g., Tachiona v. Mugabe, 169 F. Supp. 2d 259, 288-97 (S.D.N.Y. 2001). But see Saltany v. Reagan, 702 F. Supp. 319, 320 (D.C. Cir. 1988) (requiring only one paragraph to dismiss claims against British Prime Minister Margaret Thatcher on the grounds that the State Department suggestion was conclusive).

92. Hoffman, 324 U.S. at 34-35.

93. See 28 U.S.C. $\S 517$ (2000) (providing that an officer of the Justice Department may attend to the interests of the United States in any suit pending in a U.S. court).

94. See Ex parte Republic of Peru, 318 U.S. 578, 587 (1943) (deferring to the State Department's suggestion in the context of a sovereign immunity case before the enactment of the FSIA); Lafontant v. Aristide, 844 F. Supp. 128, 135 (E.D.N.Y. 1994) ("Even, however, if the goal of the United States were less lofty, it would make no difference. In this matter the courts are bound by executive decision."). 
a similar procedure in sovereign immunity cases, but that process was laid to rest by the FSIA. ${ }^{95}$ Because the FSIA addressed only the doctrine of sovereign immunity, the practice of deferring completely to State Department suggestions of head-of-state immunity continues. ${ }^{96}$

Although the executive branch often limits the courts' power to decide immunity issues, in the decades since the FSIA was enacted, federal case law has addressed in a piecemeal fashion the approach American courts will take when a justiciable head-of-state immunity issue does arise. Consistent with the treatment required by international law, ${ }^{97}$ American courts have not presumed to take jurisdiction over current or former heads of state based on their public and official acts. ${ }^{98}$ And from recent case law, one can discern that U.S. courts will recognize the immunity of foreign heads of state for private unofficial acts, even when the executive branch does not suggest immunity, when three conditions are met: (1) the person seeking immunity is a sitting head of state $;^{99}(2)$ the United States recognizes that person as the legitimate head of state ${ }^{100}$ and (3) the foreign state has not waived the immunity. ${ }^{101}$ This rule applies to all private activity, from commercial behavior to international criminal offenses, and if any of these three criteria is not met, then the defendant is not entitled to immunity in U.S. courts.

In a series of high-profile federal cases, U.S. courts addressed each of the conditions that must exist for a foreign leader to be im-

95. H.R. REP. NO. 94-1487, at 7 (1976), reprinted in 1976 U.S.C.C.A.N. 6604, 6606 (noting that one of the FSIA's principle purposes was to transfer sovereign immunity decisions from the executive branch to the judicial branch); see also Youngstown Sheet \& Tube Co. v. Sawyer, 343 U.S. 579, 635-38 (1952) (Jackson, J., concurring) (explaining that Congress has the power to enlarge or contract the scope of the executive branch's authority to a certain degree).

96. Lafontant, 844 F. Supp. at 137.

97. See supra note 44 and accompanying text.

98. See In re Estate of Ferdinand Marcos, 25 F.3d 1467, 1471 (9th Cir. 1994) (explaining that the act-of-state doctrine protects officials with sovereign authority acting in their official capacity, but not officials acting privately for personal profit).

99. See id. (denying immunity to former Philippine head of state Ferdinand Marcos).

100. See United States v. Noriega, 117 F.3d 1206, 1211-12 (11th Cir. 1997) (denying immunity to Manuel Noriega, who served as the de facto leader of Panama although the United States never recognized him as that nation's legitimate leader). The court also justified its conclusion by noting that the executive branch's decision to capture and prosecute Noriega necessarily implied an unwillingness to then provide him with immunity. Id. at 1212.

101. See Alicog v. Kingdom of Saudi Arabia, 860 F. Supp. 379, 382 (S.D. Tex. 1994) (granting immunity to King Fahd of Saudi Arabia, and recalling the long-standing practice of according immunity to sitting heads of state of governments, as recognized by the United States, when that immunity is not waived). 
mune in American courts, discussing the policy justifications served by such rules. In 1994, the Ninth Circuit decided that former heads of state enjoy no protection from lawsuits based on their private acts committed while in office. ${ }^{102}$ The lawsuit alleged that, under the authority of former Philippine head of state Ferdinand Marcos, Philippine military intelligence officials tortured, executed, or caused the disappearance of up to ten thousand people. ${ }^{103}$ Recognizing that these crimes could not be considered legitimate official acts, the court had no trouble holding Marcos accountable for his private offenses. ${ }^{104}$ "He was not the state, but the head of the state, bound by the laws that applied to him," the court declared. ${ }^{105}$ The court's decision reflected the fundamental purposes of the doctrine of head-of-state immunity in light of the shift toward a restrictive form of state sovereign immunity. As the restrictive sovereign immunity doctrine suggests, accountability for private offenses like international crimes does not unduly infringe upon state sovereignty interests. And once a head of state is no longer in office, holding him responsible for his private acts does not interfere with his nation's ability to effectively engage in diplomatic relations. ${ }^{106}$

In a 1997 criminal case against the former de facto dictator of Panama, Manuel Noriega, the Eleventh Circuit held that a foreign leader is not entitled to immunity in U.S. courts unless he is formally recognized by the U.S. government. ${ }^{107}$ In 1988, Panama's President Eric Arturo Delvalle had removed Noriega from his post as commander of Panama's defense forces, and a struggle for power ensued. ${ }^{108}$ The legislature toppled Delvalle's government, and Noriega took effective control after a disputed presidential election. ${ }^{109}$ The United States, however, recognized Guillermo Endara as the legiti-

102. In re Estate of Ferdinand Marcos, 25 F.3d at 1469-72. The State Department did not intervene in the case, so the court was free to decide the immunity question under U.S. law.

103. Id. at 1469 .

104. Id. at 1471 .

105. Id. (quoting Republic of the Philippines v. Marcos, 862 F.2d 1355, 1361 (9th Cir. 1988)). The Court also noted plaintiffs' argument that, even if Marcos had been entitled to immunity, it had been waived by the Philippine government, which had gone so far as to urge that the lawsuit against Marcos should proceed. Id. at 1472 n.7. However, the Court indicated that it was unnecessary to reach the waiver issue because the case could be decided on other grounds. Id.

106. See id. at 1472 (determining that exercising jurisdiction in the lawsuit against Marcos did not implicate foreign diplomatic concerns).

107. United States v. Noriega, 117 F.3d 1206, 1212 (11th Cir. 1997).

108. Id. at $1209-10$.

109. Id. at 1210 . 
mate constitutional head of state..$^{110}$ In December 1989, Noriega announced that a state of war existed against the United States, and, days later, the U.S. government responded with military force in an effort to seize him. ${ }^{111}$ Noriega surrendered on January 3, 1990, and American officials brought him to Florida to face drug charges. ${ }^{112}$ The court rejected Noriega's argument that he was entitled to head-ofstate immunity, noting that the United States had never recognized him as a legitimate head of state. ${ }^{113}$

Likewise, an executive determination that a person is a head of state is entitled to judicial recognition, even if that person cannot establish effective control of the nation. ${ }^{114}$ Haiti's President JeanBertrand Aristide was ousted in a military coup in 1991, but the United States continued to recognize him as Haiti's legitimate head of state. ${ }^{115}$ President George Bush continued to refer to Aristide as Haiti's "duly elected President." 116 The next U.S. administration followed suit, as President Bill Clinton described Aristide as "the democratically elected head of the Government of Haiti," mained in exile on American soil. ${ }^{118}$ Accordingly, a federal district court sitting in New York dismissed a lawsuit against Aristide that had accused him of orchestrating a political assassination, relying on the concept that Aristide enjoyed head-of-state immunity under

\footnotetext{
110. Id.

111. Id.

112. Id.

113. Id. at 1212; see also supra note 100 and accompanying text. Similarly, the Second Circuit refused to grant immunity to Radovan Karadzic, the leader of a self-proclaimed republic within Bosnia-Herzegovina called "Srpska," in a suit alleging "genocide, war crimes, and crimes against humanity." Kadic v. Karadzic, 70 F.3d 232, 236-37 (2d Cir. 1995). Srpska did establish effective control over certain territory within Bosnia-Herzegovina, but the court did not look at the qualifications for statehood under international law; rather it considered solely whether the American executive branch deemed it proper to grant formal recognition. Id. at 237, 248. In contrast, under international law, the question of what constitutes a state is not a subjective political determination, but an objective factual analysis. $I d$. at 244 . International law recognizes the existence of a state when it has a defined territory, a permanent population, effective government control over its territory and population, and the ability to carry on relations with other states. Id.

114. Lafontant v. Aristide, 844 F. Supp. 128, 131-32 (E.D.N.Y. 1994).

115. Id. at 130 .

116. Id.

117. Id. at 131.

118. Id. at 130.
} 
American law. ${ }^{119}$ Verifying that it is irrelevant whether a leader actually exercises de facto control, the court asserted that head-of-state immunity extends to the person that the executive branch recognizes as the legitimate head of state. ${ }^{120}$

The rule that only recognized heads of state are entitled to immunity limits the head-of-state immunity doctrine to situations in which foregoing accountability furthers the dual purposes of respecting state sovereign equality and protecting diplomatic functions. When two governments cease to recognize one another, there is no longer a need to foster bilateral diplomacy between them, because diplomatic relations have already broken down completely. And there is similarly no need for a government to take steps to promote the sovereign equality of an entity that it does not even acknowledge as a sovereign state by allowing its leader to escape responsibility for private wrongful acts and international crimes. In the absence of an actual diplomatic relationship between the United States and a foreign leader, the goals of head-of-state immunity cannot be considered strong enough to outweigh the interests of justice.

American law has also consistently accepted the international law concept that head-of-state immunity is a privilege granted to a foreign state for the purpose of promoting international respect, diplomacy, and comity, not a power held by the individual leader. ${ }^{121}$ Therefore, a sitting head of state recognized by the executive branch is not immune from U.S. jurisdiction if that immunity has been waived by his home country. ${ }^{122}$ Abrogating immunity in the case of waiver leaves the goals of promoting sovereign equality and diplo-

119. Id. It was sufficient to decide this case that the State Department entered a binding suggestion of immunity on behalf of Aristide. Id. at 135 . However, the court nevertheless elucidated the rule regarding head-of-state immunity in U.S. courts, giving special attention to the requirement that the person be recognized as a head of state by the executive branch. $I d$. at 132 .

120. Id. at 132 ("Recognition of a government and its officers is the exclusive function of the Executive Branch.”); see also United States v. Pink, 315 U.S. 203, 230 (1942) (deferring to the executive branch's recognition of the Soviet Union).

121. See In Re Grand Jury Proceedings, Doe, 817 F.2d 1108, 1110-11 (4th Cir. 1987) ("Headof-state immunity is founded on the need for comity among nations and respect for the sovereignty of other nations .... Our view is that head-of-state immunity is primarily an attribute of state sovereignty, not an individual right."); see also Alicog v. Kingdom of Saudi Arabia, 860 F. Supp. 379, 382 (S.D. Tex. 1994) (granting immunity to King Fahd of Saudi Arabia and suggesting that Saudi Arabia had not waived that immunity).

122. See id. (describing the waiver rule as a long-standing principle of international law). 
macy intact, because it does not permit jurisdiction to be exercised without the interested state's consent. ${ }^{123}$

However, all of this domestic precedent predated the dramatic shift in the law of head-of-state immunity under international law that had taken place since the Pinochet case. ${ }^{124}$ As a result, the murky state of the law of head-of-state immunity in the international sphere was no clearer under domestic U.S. law, and in light of recent developments on the world stage, it remained uncertain whether U.S. courts would adhere to the principles espoused in the Marcos, Noriega and Aristide cases in the future. ${ }^{125}$ In the Mugabe case, a federal district court for the first time was called upon to decide whether the recent changes in the customary international law of head-of-state immunity-such as the elimination of immunity of former heads of state for international crimes and other private acts-would cause U.S. courts to rethink their approach to the head-of-state immunity doctrine in the domestic sphere. ${ }^{126}$

\section{B. The District Court's Mugabe Decision}

Zimbabwe's President Robert Mugabe visited New York in September of 2000 to meet with other diplomats and world leaders at the United Nations Millennium Summit. ${ }^{127}$ During the trip, he held a rally at a Harlem church in an attempt to drum up American popular support for his controversial policy of backing violent seizures of whiteowned farms in Zimbabwe. ${ }^{128}$ As President Mugabe arrived at the

123. In practice, it is extremely uncommon for a sitting head of state's immunity to be waived because he is often the person who has the power to control whether or not to issue a waiver. This catch-22 is illustrated in the Aristide case. The de facto Haitian government supported the lawsuit and tried to waive Aristide's immunity, but it was unable to do so because Aristide represented the only Haitian government recognized by the United States; consequently, only Aristide could waive his own immunity. See Lafontant, 844 F. Supp. at 134 ("Because the United States does not recognize the de facto government, that government does not have the power to waive President Aristide's immunity."). In the days in which former heads of state were immune from suits based on their private acts, waiver played a more potent role. However, it is possible that waiver could arise again as a significant limit to the head-of-state immunity doctrine, as precedents like the ICC raise the possibility that a state may waive its leaders' immunity in advance. See supra notes 53-55 and accompanying text.

124. See supra notes 35-59 and accompanying text.

125. See supra note 1 and accompanying text.

126. Tachiona v. Mugabe, 169 F. Supp. 2d 259, 278-81 (S.D.N.Y. 2001).

127. Zimbabwe President Accused of Orchestrating Terror in U.S. Suit, CNN.com, at http:// www.cnn.com/2000/WORLD/africa/09/10/us.mugabesued.ap/ (Sept. 10, 2000) (on file with the Duke Law Journal).

128. Id. 
church, he was served with a lawsuit ${ }^{129}$ alleging that he had organized assassinations, torture, rapes, terrorism, and other acts of violence in a campaign designed to quash his political opposition. ${ }^{130}$ The complaint listed pages of specific instances of abuse against members of the opposition party, Movement for Democratic Change (MDC), ${ }^{131}$ and accused President Mugabe of encouraging these crimes by repeatedly threatening violence against opponents of the ruling ZANUPF party. ${ }^{132}$ President Mugabe had allegedly warned MDC voters that "my ghost will come after you," and that "those who try to cause disunity among our people must watch out because death will befall them." 133

In the Mugabe case, the U.S. State Department submitted an official suggestion to the court declaring that President Mugabe should be entitled to head-of-state immunity in U.S. courts. ${ }^{134}$ The suggestion stressed that putting President Mugabe on trial would be incompatible with America's foreign policy goals. ${ }^{135}$ Although the Mugabe court went on to discuss the domestic and international law of head-of-state immunity in detail, it recognized that no American court has ever ignored a State Department request for immunity for a head of state, ${ }^{136}$ and acknowledged that no act of Congress has overturned this long-

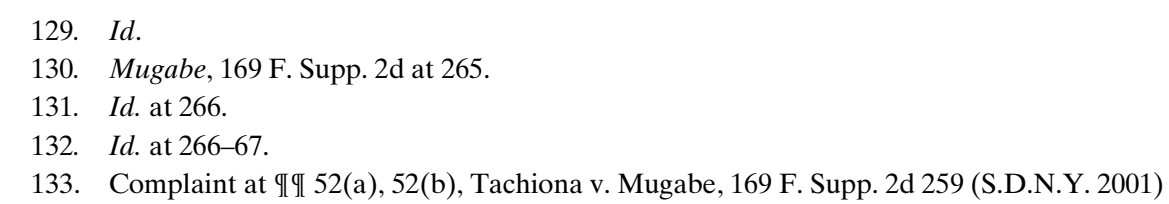

133. Complaint at IIII 52(a), 52(b), Tachiona v. Mugabe, 169 F. Supp. 2 d 259 (S.D.N.Y. 2001) ordinates and other leaders of the ruling party, including Defense Minister Moven Mahachi and Zimbabwe War Veterans Association President Chenjerayi Hunzvi, who is called by his adopted middle name "Hitler." Id. at II II 4, 50. For example, Mahachi reportedly told voters at a village meeting that "if you are going to vote for MDC we will see what you have voted for, because we will have machines in these polling stations. After the election we will move around from door to door at every house beating you." Id. at If 50(e).

134. Mugabe, 169 F. Supp. 2 d at 267.

135. Id. However, some voices within the U.S. government expressed a different view. For instance, U.S. Congressman Henry Hyde warned against using the doctrine of head-of-state immunity to assist a political regime that denied basic democratic rights to its own people. See Henry J. Hyde, U.S. Shouldn't Rush to Protect Mugabe, CHI. TRIB., Feb. 19, 2001, at 19. ("The State Department must be careful that its desire to support the tradition of reciprocal diplomatic immunity does not lend aid and comfort to a brutal regime's political war on its own citizens.").

136. See Mugabe, 169 F. Supp. 2d at 294-95 (citing Republic of Philippines v. Marcos, 665 F. Supp. 793, 797-98 (N.D. Cal. 1987), as the only instance in which a court has refused to follow a State Department suggestion, a case involving not a head of state, but rather a foreign state's solicitor general). 
standing practice. ${ }^{137}$ The State Department's determination that granting President Mugabe immunity served American foreign policy interests was therefore wholly conclusive.

Nevertheless, the Mugabe court proceeded to address the dramatic changes that had recently taken place in the law of head-ofstate immunity, both on the domestic and international fronts. Significantly, the court emphasized that the American domestic law of head-of-state immunity is distinct from the related concepts of state sovereign immunity and diplomatic immunity, though the three doctrines do share some of the same aims. As the court explained, "substantial case law has begun to develop, identifying issues singularly associated with head-of-state immunity and demanding treatment under a set of rules reflecting that uniqueness." ${ }^{, 138}$ Bringing together and reaffirming the precedent previously established in U.S. courts, the Mugabe court held that head-of-state immunity applies under U.S. law only to recognized foreign leaders when the immunity is not waived by the state. ${ }^{139}$ Moreover, the court noted that the international law and American domestic law of head-of-state immunity are consistent with one another. "Importantly, to some degree, progression in the international sphere either mirrors or has been driven by comparable evolution of principles on the domestic front," the court observed. ${ }^{140}$

Applying the principles recognized by the Mugabe court, it is evident that President Mugabe would have been entitled to head-ofstate immunity even if the executive branch had not pressed for it. President Mugabe served as the sitting head of state of Zimbabwe, he was recognized as a head of state by the United States government, and Zimbabwe had not waived his immunity. Therefore, he was entitled to travel to the United States without apprehension that he could be placed on trial for his private acts, including even serious violations of international criminal law. ${ }^{141}$

137. See id. at 288 (describing the role of State Department suggestions in the "emerging consensus" regarding the American law of head-of-state immunity).

138. Id. at 277.

139. Id. at 292 ("As Noriega and Aristide demonstrate, head-of-state immunity is an attribute of state sovereignty, not an individual right ... [H] ead-of-state status requires a formal act of recognition by the Executive Branch, and only officials so recognized can claim entitlement to the corresponding privileges and immunities.").

140. Id. at 280 .

141. The court went on to hold that Mugabe's head-of-state immunity did not also vest immunity in the ZANU-PF political party that he controlled, and that it was valid to give the political party notice of the suit through the service of process on Mugabe, the party's first secre- 


\section{THE NEW FRAMEWORK FOR THE LAW OF HEAD-OF-STATE IMMUNITY}

As the foregoing discussion demonstrates, American courts and international courts are essentially in agreement as to when a state's courts are required to recognize the immunity of foreign heads of state. Consistent with the framework articulated by the ICJ, U.S. courts will grant a recognized sitting foreign leader immunity, absent waiver by the foreign state. Significantly, international law also permits states the discretion to grant foreign leaders a greater degree of immunity, and the United States has placed the responsibility for determining when to exercise this discretion in the hands of the executive branch. This framework leaves U.S. policymakers substantial flexibility in seeking accountability though political means, and furthers the purposes of the head-of-state immunity doctrine by eliminating the chilling effect on diplomacy that stems from uncertainty about the legal scope of head-of-state immunity.

\section{A. The Legal Pedigree}

To a large extent, the Yerodia and Mugabe courts harmonized the international and domestic law of head-of-state immunity, forging a coherent framework that protects the functional purpose of immunity while leaving open ways of attaining accountability for international crimes. Both courts upheld the basic doctrine that sitting heads of state and other top state officials enjoy absolute immunity while in office, unless the immunity is waived by the state. Both clearly laid out consistent standards governing when a state's former leaders are entitled to receive immunity in foreign courts, substantially clarifying the law in this once cloudy area. ${ }^{142}$ Furthermore, both endorsed headof-state immunity primarily on grounds mirroring the functional purposes of diplomatic immunity, according substantially less weight to other historical justifications rooted in the doctrine of state sovereign immunity and the notion of sovereign equality. In drawing this distinction, the decisions explain why some aspects of head-of-state immunity have been abandoned in the name of accountability for international crimes, whereas others must be retained to promote international discourse and diplomacy.

tary. Id. at 307-09. Because ZANU-PF, like Mugabe, refused to appear before the court, the court entered a default judgment against ZANU-PF and ordered the case referred to a magistrate judge to determine damages. $I d$. at 318 .

142. See supra notes 71-75, 97-101, 138-141 and accompanying text. 
The concept of restrictive sovereign immunity has accepted the notion that seeking accountability for international crimes and other unofficial acts does not undermine the principles of sovereign equality and independence. Therefore, the doctrine of head-of-state immunity must also accept that these goals are no longer sufficient to justify awarding immunity to heads of state. Instead, head-of-state immunity for international crimes is now justifiable primarily to protect world leaders' ability to effectively carry out their diplomatic functions. As the Mugabe court explained, "If there is a larger end here to be served, for which accusations of grave misconduct as between particular individuals may be momentarily set aside, it is in the interest of comity among nations - to safeguard friendly relations between sovereign states." 143 Because neither former heads of state nor leaders who are not recognized by the United States have essential diplomatic interests that require free travel in the United States, they are not entitled to the immunity afforded to recognized sitting foreign leaders in American courts. ${ }^{14}$

In contrast, protecting the inviolability of sitting heads of state for both public and private acts is still consistent with the fundamental justifications for the head-of-state immunity doctrine. A rule ensuring that a nation's leader is not put on trial for official public acts respects that nation's sovereign equality and prevents other states from using their judiciaries to influence another nation's legitimate political decisions. These are goals that are still ardently endorsed under the restrictive form of sovereign immunity. ${ }^{145}$ Furthermore, protecting sitting heads of state from foreign jurisdiction even with respect to private acts helps world leaders freely engage in their unique diplomatic functions. ${ }^{146}$ A strong form of immunity for sitting heads of

143. Mugabe, 169 F. Supp. 2d at 317.

144. Likewise, the ICJ reasoned that even "the mere risk that, by travelling to or transiting another State a Minister for Foreign Affairs might be exposing himself or herself to legal proceedings could deter the Minister from travelling internationally when required to do so for the purposes of the performance of his or her official functions." Arrest Warrant of 11 April 2000 (Congo v. Belg.), 41 I.L.M. 536, 550 (2002).

145. See supra notes 7-12 and accompanying text.

146. See Lafontant v. Aristide, 844 F. Supp. 128, 132 (E.D.N.Y. 1994) ("Heads of state must be able to freely perform their duties at home and abroad without the threat of civil and criminal liability in a foreign legal system."); Mallory, supra note 4, at 193 ("Compelling reasons exist for according heads of state a greater degree of immunity .... [H] eads of state often perform diplomatic and political functions when in the United States, and as ceremonial and governmental representatives of their states, they are entitled to a degree of immunity consistent with their official status."). 
state therefore helps encourage productive international relations by promoting travel and discourse between sovereign nations.

\section{B. Seeking Accountability: Legal and Political Options}

As the Yerodia and Mugabe cases indicate, it is now clear that the head-of-state immunity doctrine requires states to respect the inviolability of sitting state leaders. However, this framework leaves states a great deal of political discretion to determine whether to exercise jurisdiction over others who formerly would have enjoyed immunity, such as former heads of state accused of international crimes. In these cases, states now have the political flexibility to seek civil and criminal accountability when they deem it appropriate to do so.

Continuing to recognize the immunity of sitting heads of state comes with a cost: under some circumstances the immunity doctrine can restrict victims' access to the courts, and it may give human rights violators an incentive to hold onto power. ${ }^{147}$ But upon deeper analysis, it may be that in practice these costs are not so great as they initially appear. It is not at all clear that the alternative-further eroding the concept of head-of-state immunity-would have any appreciable impact on efforts to bring the perpetrators of international crimes to justice. The framework crystallized in the Yerodia and Mugabe decisions strikes a responsible balance that allows states to pursue accountability in many circumstances, but stops short of creating jurisdiction over foreign leaders that those leaders could easily avoid.

Although it is possible (though far from certain) that a sudden shift in the law might allow U.S. courts initially to render judgments against a few unwary head-of-state defendants, it is highly doubtful that this course would bear fruit as a long-term strategy for holding accountable heads of state who perpetrate genocide, war crimes, crimes against humanity, or similar atrocities. Just as many heads of state recently became leery about setting foot in Belgian territory, ${ }^{148}$ if the United States elected (in violation of international law) to open its courts as a forum to try world leaders for international crimes, then those leaders who have something to fear could simply avoid trial by refusing to risk travel to the United States, even for diplomatic functions. Stripping away sitting-head-of-state immunity for

147. See supra notes $25-27$ and accompanying text.

148. See supra notes 30-31 and accompanying text. 
private acts probably would not increase accountability but rather decrease the use of diplomatic channels.

Moreover, the international law of head-of-state immunity affords national legal systems the flexibility to grant a greater degree of immunity to foreign heads of state and other top officials, either as a domestic legal rule or on a case-by-case basis pursuant to political decisionmaking. ${ }^{149}$ Under this framework, states may fashion targeted case-specific strategies to prevent human rights violators from clinging to power to avoid trial. For example, the executive branch could agree to recognize an amnesty agreement as part of a negotiated transition of power to a friendly regime. This approach interacts well with the United States' presumptively political approach to head-of-state immunity questions, in which the executive branch may make binding suggestions of immunity. As former U.S. Ambassador for War Crimes Issues David Scheffer explains, "Immunity may be the rogue elephant at the party, but a rogue we may come to appreciate to establish greater ability for international politics to function." ${ }^{150}$

In addition, the modern framework for deciding head-of-state immunity questions contains a number of methods to improve accountability while still promoting friendly diplomatic ties: "It is well to consider also that justice and injustice, paired like strands of life, normally travel hand in hand, their union joined in direct proportion .... The greater the wrong, the louder the cry for right to be requited." ${ }^{151}$ While respecting the functional need for head-of-state immunity, the framework articulated by the Yerodia and Mugabe courts provides nations with several ways to seek accountability from particular violators of fundamental human rights norms.

First, it is important to remember that the head-of-state immunity doctrine does not give sitting heads of state the power to act outside the law. ${ }^{152}$ Instead, it places procedural restrictions on when other

149. For a discussion of when national courts may exercise jurisdiction, see supra Part II.B.

150. David Scheffer, Universal Jurisdiction: Myths, Realities, and Prospects, 35 NEW ENG. L. REV. 233, 239 (2001).

151. Tachiona v. Mugabe, 169 F. Supp. 2d 259, 318 (S.D.N.Y. 2001) (noting that the law of head-of-state immunity is capable of changing to respond to injustice, and observing that "the vanguard of the law should stand ready to adapt as appropriate, to shape redress and remedy so as to answer measure for measure the particular evil it pursues").

152. See In re Estate of Ferdinand Marcos, 25 F.3d 1467, 1471 (9th Cir. 1994) (emphasizing that Marcos, even while in power as the head of state, was "bound by the laws that applied to him"). 
states are permitted to bring them to justice..$^{153}$ As the ICJ emphasized, "Jurisdictional immunity may well bar prosecution for a certain period or for certain offences; it cannot exonerate the person to whom it applies from all criminal responsibility." leader who has committed international crimes leaves office or is forced from power, he no longer enjoys the protections of head-ofstate immunity for those crimes under international or U.S. law.

Second, acting in concert with other major powers, the United States could support stripping away the immunity of certain sitting heads of state on an ad hoc basis under the Chapter VII authority of the UN Security Council. Strategies under Chapter VII could include establishing an international tribunal empowered to try heads of state, following the example of the ICTY and ICTR, or authorizing states to try particular alleged human rights violators and war criminals in their domestic courts. ${ }^{155}$ Unlike efforts to make systematic changes in the law, these political options would require neither a new treaty nor a change in international custom.

Finally, in extreme cases, the United States may elect to revoke official diplomatic recognition from certain world leaders or regimes that have committed particularly heinous international crimes, meaning that those leaders would no longer be entitled to head-ofstate immunity in American courts. Such a course of action would essentially operate like a persona non grata rule, ${ }^{156}$ abrogating a foreign leader's immunity in advance at the cost of disturbing diplomatic relations with that particular country, and not necessarily with the entire international community. Although such a step would carry dramatic political consequences, such consequences would be less severe than if the United States simply purported to subject recognized foreign leaders to its criminal justice process without warning. National political branches would have the flexibility to weigh the costs and benefits of such a course of action on a fact-specific, case-by-case basis.

153. See Tachiona, 169 F. Supp. 2d at 317 (noting that, under the immunity doctrine, the head of state's offenses are not forgiven, but merely set aside momentarily).

154. Arrest Warrant of 11 April 2000 (Congo v. Belg.), 41 I.L.M. 536, 551 (2002).

155. See supra notes 57-59 and accompanying text.

156. See Vienna Convention on Diplomatic Relations, supra note 14, art. 9, 23 U.S.T. at 3233-34, 500 U.N.T.S. at 102. The Vienna Convention allows receiving states to declare a foreign diplomat persona non grata. Id. In response, the sending state must recall that diplomat within a reasonable time period, or else the receiving state may refuse to recognize him as an immune member of the diplomatic mission. Id. 


\section{The Benefits of Legal Certainty}

The framework that has emerged for settling questions of headof-state immunity also promises to put an end to the lack of stability and predictability that has plagued the head-of-state immunity doctrine in recent years. The recent confusion over the scope of head-ofstate immunity has itself hindered the diplomatic purposes underlying that doctrine. ${ }^{157}$ For head-of-state immunity to accomplish its goal of encouraging diplomatic discourse, world leaders must be able to rely on a stable and predictable legal rule. ${ }^{158}$ Uncertainty in this area of the law can shut down diplomatic channels just as surely as actual erosion of the immunity traditionally afforded to a state's highest leaders.

For this reason, the United States should endorse the framework articulated in the Yerodia and Mugabe cases as a stable and lasting customary rule. As the ICJ explained in the Yerodia Arrest Warrant case, the state practice that currently exists supporting further erosion of the head-of-state immunity doctrine is not strong enough to develop new customary law. ${ }^{159}$ However, if states continue to whittle away at head-of-state immunity in spite of the ICJ's opinion, the scope of immunity enjoyed by world leaders could once again be cast into doubt. By following the precedent established in Mugabe, the U.S. judicial branch can create state practice solidifying the current customary framework. The executive branch should follow suit by endorsing the framework articulated in Yerodia and Mugabe and by denouncing any deviation from that framework by foreign states. Moreover, the United States ought to encourage codification of the current customary framework in an international treaty to ensure the continued stability and predictability of the head-of-state immunity doctrine in its current form.

A law of head-of-state immunity mired in confusion and instability is powerless to achieve its diplomatic objectives. The framework reflected in the Yerodia and Mugabe cases promises to resolve that confusion, restoring the head of immunity doctrine as an effective

157. See Keinon, supra note 31, at 4A (discussing Israeli Prime Minister Ariel Sharon's reluctance to travel to certain countries to avoid the possibility of being subjected to jurisdiction there).

158. See Lori Fisler Damrosch, Politics Across Borders: Nonintervention and Nonforcible Influence Over Domestic Affairs, 83 AM. J. INT'L L. 1, 13 (1989) (noting that, when diplomatic functions are involved, "each state knows that it will occupy both roles [that is, the roles of both sending and receiving state] at all times and ... consistency and predictability seem to serve all states' interests").

159. See supra notes $48-59,71-75$ and accompanying text. 
means of promoting international diplomacy. U.S. policymakers must recognize, however, that this promise could be lost if states do not actively support this framework through state practice and resist any attempts by other states to modify it.

\section{CONCLUSION}

The Mugabe court held that head-of-state immunity prevented it from forcing Zimbabwe's president to answer allegations of murder, torture, and terrorism. ${ }^{160}$ The court, however, also tried to assure the victims of international crimes that all is not lost. ${ }^{161}$ Such tension in the law of head-of-state immunity has sparked intense debate in recent years about how best to balance the fundamental values of sovereignty, diplomacy, and justice. American and international courts responsibly resolved the dispute by forging a system in which immunity both retains its crucial role in international diplomacy and coexists with mechanisms that allow nations to seek accountability for international crimes regardless of the status of the perpetrator. Because uncertainty has traditionally haunted head-of-state immunity doctrine, the United States should continue to work both domestically and abroad to reinforce this framework as a lasting solution.

160. Tachiona v. Mugabe, 169 F. Supp. 2d 259, 318 (S.D.N.Y. 2001).

161. See id. at 317 ("[T] he day does come to pass when those who violate their public trust are called upon, in this world, to render account for the wrongs they inflict on innocents."). 